\title{
APPLICATION OF THE HIGH PRESSURE TORSION SUPPORTED BY MECHANICAL ALLLOYING FOR METAL-GRAPHENE COMPOSITES PREPARATION
}

\author{
ZASTOSOWANIE SKRĘCANIA WYSOKOCIŚNIENIOWEGO \\ WSPOMAGANEGO STOPOWANIEM MECHANICZNYM \\ NA POTRZEBY WYTWARZANIA KOMPOZYTÓW METAL-GRAFEN
}

\author{
Tomasz CZEPPE ${ }^{1}$, Elena KORZNIKOVA ${ }^{2}$, Piotr OZGA ${ }^{1}$, \\ Lidia LITYŃSKA-DOBRZYŃSKA ${ }^{1}$, Robert SOCHA ${ }^{3}$
}

\begin{abstract}
From the time when the method of a monolayer graphene preparation was published the scientific activity concerning the properties, production and application of this special form of carbon is very intensive. Graphene is two dimensional (2D) crystalline material, stable in a wide temperature range, possessing unusual electronic,electrical, thermal and mechanical properties. Graphene and the graphene oxide properties may be used in the range of the metal matrix composites, in which case graphene particles may improve electrical and thermal conductivity or/and strength of the material. The paper presents results of the studies concerning application of the high pressure torsion, one of the method of intensive deformation of metals to the powders consolidation to the homogenous composite metal-graphene structure. The aluminum and copper - graphene compositions were investigated. It was found that mechanical alloying as the preliminary step increased density and microhardness of the samples achieved by the High Pressure Torsion. As a result small, thin and round samples of composites and similar metallic samples not containing graphene, about $10 \mathrm{~mm}$ in diameter were achieved. The X-ray diffraction (XRD), transmission electron microscopy (TEM), Raman spectroscopy and X-ray photoelectron spectroscopy (XPS) were applied to study structure and analyze graphene content and atomic bonds. The Raman spectroscopy proved the presence of the multilayer graphene which could also be identified as the defected nano-graphitc as a component of the composite structure. In case of the Algraphene composites small content of the aluminum carbides was detected as well. The metallic matrices of the samples revealed highly dispersed microstructures transmission electron microscopy show, in dependence on the number of rotations applied in the High Pressure Torsion process, leading to the increased plastic deformation of the consolidated
\end{abstract}

\footnotetext{
${ }^{1}$ Institute of Metallurgy and Materials Sciences, Polish Academy of Sciences, Krakow, Poland

${ }^{2}$ Institute for Metals Superplasticity Problems, Russian Academy of Sciences, Ufa, Russia

${ }^{3}$ Instutute of Catalysis and Surfaces Chemistry, Polish Academy of Sciences, Krakow, Poland
} 
material. The XPS method revealed increased amount of the carbon-metal and carbon- metaloxygen atomic bonds in the case of the metal-graphene composites, suggesting partial transformation of the multilayer graphene in the graphene due to the high range of deformations applied.

Keywords: high pressure torsion, metal-graphene composite, mechanical alloying, structure study

Streszczenie: Praca przedstawia wyniki badań dotyczących próbek z proszku aluminium i kompozytów aluminium-grafen, wytworzonych w dwóch etapach: mechanicznej syntezy mieleniem i intensywnego odkształcenia metodą skręcania pod wysokim ciśnieniem. Wytworzono próbki w postaci okrągłej, o średnicy około $10 \mathrm{~mm}$, charakteryzujące się znaczną jednorodnością mikrostruktury w przekroju. Zastosowanie wstępne mechanicznej syntezy podniosło mikrotwardość próbek i stopień kompresji. Dodatek grafenu nie miał wpływu na te parametry. Przeprowadzono badania metodami transmisyjnej mikroskopii elektronowej, spektroskopii Ramana i spektroskopii fotoelektronów XPS. Wyniki transmisyjnej mikroskopii elektronowej i spektroskopii Ramana wskazują na równomierne rozłożenie cząstek grafenu na powierzchni ziaren matrycy. Zwiększenie odkształcenia ścinającego w metodzie skręcania pod wysokim ciśnieniem prowadzi do silniejszego rozdrobnienia struktury matrycy i cząstek grafenu. Jak wynika ze spektroskopii Ramana, wprowadzony grafen może być zakwalifikowany jako grafen wielowarstwowy, zdefektowany. Konsolidacja przy pomocy intensywnego odkształcenia skręcaniem pod wysokim ciśnieniem zwiększa zdefektowanie i dyspersję grafenu oraz prawdopodobnie zwiększa zawartość grafenu o małej ilości warstw. Metoda XPS wskazuje na powstawanie wiązań atomowych węgiel-glin i zmniejszenie udziału wiązań węgiel-węgiel i glin-glin. Stwierdzono także tworzenie się niewielkiej ilości węglików aluminium.

Stowa kluczowe: skręcanie wysokociśnieniowe, kompozyt metal-grafen, stopowanie mechaniczne, analiza struktury

\section{INTRODUCTION}

Since the graphene as two dimensional (2D), essentially defect-less carbon form was defined and the first methods of production were given [1-3], the scientific effort concerning graphene physical and chemical properties and different methods of preparation, as well as it's physical and chemical properties is very large. Essentially graphene is two dimensional (2D) crystalline material, stable in a wide temperature range, possessing unusual electronic, electrical, thermal and mechanical properties [1,4,5,6]. Particularly, the high electron mobility end extreme electrical conductivity makes graphene a promising material for the future application in micro-electronics [7]. Also, the mechanical properties like extremely high strength of the order of $42 \mathrm{~N} / \mathrm{m}$, related to the large intrinsic strain, in the range of $25 \%$ and Young's modulus in the range of 1.0 TPa [8] are excellent. Consequently, the graphene applications become one of the new, current subjects in materials sciences. The main effort concerns the new graphene based electronics [9], the application in catalysis and composite structures including polymers and graphene or graphite oxides.

The interest in graphene caused also new interest in the graphite oxide, which was known much earlier than graphene, but was not recognized as a material promising in technology [10]. Presently the graphite oxide is used as the precursor for the production of the larger 
volumes of graphene by the reduction processes [10].

Unusual properties of the graphene caused that graphene potentially could be extremely valuable as a component of the "classical" metal-matrix composites. Less effort was done about that than in the other areas of application, e.g. use of graphene in the polymer-graphene composites. In case of the metal matrix composites, the graphene sheets could improve electrical and thermal conductivity of the electrical elements or/and strength of the material. The last could be extremely valuable in case of the light structural composite materials, leading both to the higher strength and lower mass of the product. Also graphene oxide may be used as a strengthening component of the metalic composites [10].

However, the different problems should be mentioned. The product named grafen is commercially available from many sources. The precise investigations shows that such products needs commonly additional verification as commonly contains very different forms of carbon, from graphite with some participation of graphene to such named multi-layer graphene [11]. The Raman spectroscopy remains one of the most important methods for such characterization. It also not clear how far the unique graphene properties may be preserved in case of the graphene incorporated into metal composite structure and what kind of atomic bonds should be formed with surrounding matrix to achieve required properties.

High Pressure Torsion (HPT) belongs to the methods introducing extremely large deformations into materials by large shearing stresses acting in the hydrostatically deformed states [12]. Originally the method was used for modification of microstructure of the crystalline metals and alloys, also in the case of brittle intermetallic phases [13]. By the application of HPT to the multi-phase alloys different results may be achieved. Except expected strong decrease of the grain size down to the nano-dimensions and micro-twin generation [13] in some cases atomic disordering, sometimes much more effective than by rapid quenching may result $[14,15,16,17]$. In some cases formation of metastable phases by intensive deformation have place. What more it was proved that HPT may be used as a method for the direct consolidation of powders, in the case of metallic glasses lack of the temperature increase may preserve amorphous structure of materials $[18,19]$.

Consequently, it may be assumed that the method may be also useful for the consolidation of the metal powders with graphene for the composite structure formation. The advantage of the method would be relative simplicity of the production procedure operating at room temperature. The idea of the presented paper was to investigate possibility of the HPT application for the metal-graphene composite production and the properties of such material in case of the $\mathrm{Al}$, as a metallic matrix. Papers presenting similar results are not known to the authors.

\section{EXPERIMENTAL}

The Al powder of the purity 99,99 and with particles of the approximate size $1 \mu \mathrm{m}$ was used. Two procedures of Al powder consolidation were applied. The graphene containing product was produced by the Novosibirsk Scientific Center of Siberian Branch of Russian Academy of Sciences. For the composite the powder of Al was mixed with the $0.05 \mathrm{wt} \%$ addition of the graphene. First, the Al powder was consolidated seldom by the HPT. Similar sample was prepared after mechanical alloying. Due to the examination of the $\mathrm{Al}$ consolidated samples the mechanical alloying as a preliminary step was also applied in case of the Al-graphene composites production. The mechanical alloying was performed in the 
following way:

- planetary ball mill Retsch, type PM 400 was used

- special steel balls with ball-to-powder weight ratio of 20:1 were applied

- ball milling was performed up to $7.5 \mathrm{~h}$, with the speed $150 \mathrm{rpm}$

- milling was stopped after each $1 \mathrm{~min}$ for $30 \mathrm{sec}$ to avoid temperature increase,

- mechanical alloying was performed in the air.

Subsequently HPT consolidation was applied with typical hydrostatic pressure of $4 \mathrm{GPa}$ and 5 rotations. A small amount of powder was placed on the anvils of unconstrained type of the diameter $10 \mathrm{~mm}$. The method schematically is presented in Figure 1a. As a result bulk samples in the form of thin discs about $10 \mathrm{~mm}$ in diameter were achieved. The second series of the samples was made with the number of rotations increased to 10 . The typical sample is shown in Figure 1b. To determine basic properties of the samples the Vickers microhardness was determined.

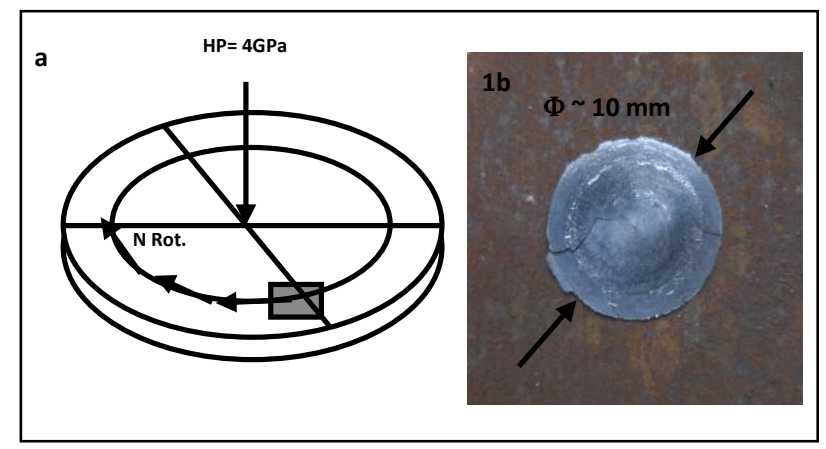

Figure 1. Schematic presentation of the stresses involved in HPT method (a) and the typical Al consolidated sample produced with use of HPT (b)

The cross-sections of the samples were further investigated with optical confocal microscopy. Transmission electron microscopy (TEM) was applied to identify macro- and microstructure. The Raman spectroscopy was used to identify graphene content. For this type of investigations thin foils were prepared with use of the Fine Ion Beam (FIB) technique. MicroRaman spectra were taken using a Renishaw inVia Raman microscope $(50 \mathrm{x}$ or $100 \mathrm{x}$ objectives) with $633 \mathrm{~nm}$ He-Ne excitation laser and 100\% laser power (21 mW output power), with spatial resolution better than $1 \mu \mathrm{m}$. To identify types of atomic bonding the photoelectron spectroscopy (ESCA/XPS) was applied. The experiments were performed with hemispherical analyser SES R4000 (Gammadata Scienta), and Al Ka (1486.6 eV) excitation in vacuum of the $3 \cdot 10^{-9}$ mbar. To enable samples volume analysis the surface layers were removed by the Ar ion etching during 10 minutes operation. The thermal stability of the samples was investigated with the DSC calorimetry. DSC Q1000 TAI calorimeter was used. There is no one accepted formula for the sample deformation in HPT method. In the paper the shear strain $\gamma$ was calculated with the formula:

$$
\gamma=2 \pi \mathrm{N}(\mathrm{R} / \mathrm{D})(1)
$$



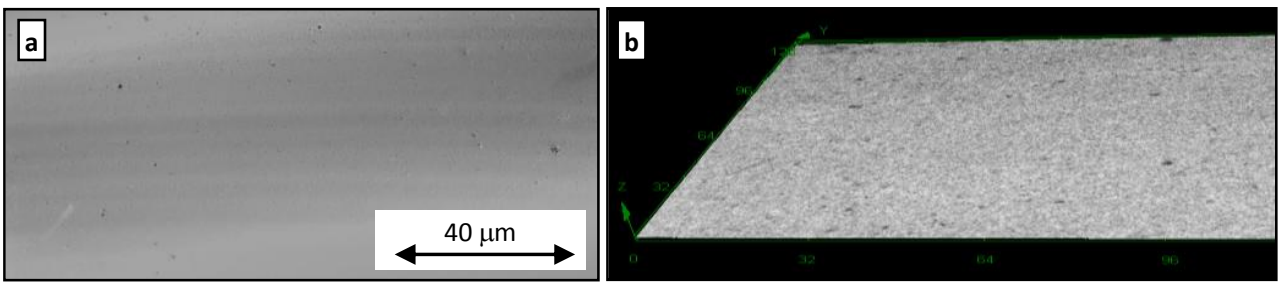

Figure 2. Confocal light microscopy. The microstructure in the cross-section of the Al-graphene sample No. 3. (a) - 2D image, decrease of brightness related to the increase in $\mathrm{Z}$ axis direction, (b) - 3D reconstrctioncen

and equivalent strain $\varepsilon$ with the formula:

$$
\varepsilon=\left(2 / 3^{1 / 3}\right) \ln \left[\left(1+\gamma^{2} / 4+\gamma / 2\right)^{1 / 2}\right]
$$

in both formulas $\mathrm{D}$ is the final thickness of the sample and $\mathrm{R}$ the radius from the center to the deformed point [20].

\section{RESULTS}

Comparison of the density, microhardness and the relative compression $\left(D-D_{0}\right) / D_{0}$ between two graphene-less Al samples 1 and 2 (Table 1), prepared seldom by HPT consolidation and preliminary ball milled (BM) showed that both microhardness and compression were larger in case of the sample 2 subdued to the BM process (Table 1). The microhardness was measured in the sample centre, where essentially deformation by shearing was minimal and at the edges, where the deformation must be enhanced (see formula 1). The relative compression, measured as relative decrease of the samples thickness $\mathrm{D}$ at the edges and in the centre $\left(D_{0}\right)$ increased from $32 \%$ for the sample 1 to $47 \%$ for the sample 2 . The presented results suggested that mechanical synthesis my increase both deformation ability and properties of the Al-graphene composites.

Table 1. Samples composition, method of preparation, equivalent strain $\varepsilon$ and microhardnes $\mu \mathrm{HV}$

\begin{tabular}{|c|c|c|c|c|c|c|}
\hline No. & $\begin{array}{c}\text { Sample } \\
\text { composition }\end{array}$ & $\begin{array}{c}\text { Preparation } \\
\text { method }\end{array}$ & $\begin{array}{c}\text { BM time in hours/ } \\
\text { number } \\
\text { of rotations N }\end{array}$ & $\varepsilon$ & $\begin{array}{c}\mu \mathrm{HV} \\
\text { in center } \\
{[\mathrm{GPa}]}\end{array}$ & $\begin{array}{c}\mu \mathrm{HV} \\
\text { at the edge } \\
{[\mathrm{GPa}]}\end{array}$ \\
\hline 1. & $\mathrm{Al}$ & HPT consolidation & $0 / 5$ & ------ & 0.9 & 1.6 \\
\hline 2. & $\mathrm{Al}$ & $\begin{array}{c}\text { Ball milling + HPT } \\
\text { consolidation }\end{array}$ & $7.5 / 5$ & 760 & 1.5 & 2.0 \\
\hline 3. & $\mathrm{Al}+0.05 \mathrm{wt} \% \mathrm{Gr}$ & $\begin{array}{c}\text { Ball milling + HPT } \\
\text { consolidation }\end{array}$ & $7.5 / 5$ & 760 & 1.5 & 2.0 \\
\hline 4. & $\mathrm{Al}+0.05 \mathrm{wt} \% \mathrm{Gr}$ & $\begin{array}{c}\text { Ball milling + HPT } \\
\text { consolidation }\end{array}$ & $7.5 / 10$ & 830 & ------- & -- \\
\hline
\end{tabular}

Consequently, the ball milling was introduced as a preliminary step to HPT consolidation in case of the samples 3 and 4 (Table 1). However, as is visible from Table 1 the graphene 
addition did not influence the microhardness of the composite samples prepared with the same rotation number $\mathrm{N}=5$. The same concerns relative compression. The images done at the cross-sections of the sample 3 (Fig. 2) in 2D and 3D proved homogeneity of the microstructure after consolidation, showing as well that dark objects of the microstructure reveal tendency to build up above the polished surface of the composite.

The increase in the rotation number in HPT consolidation process leads to the increase in the shear and equivalent strains (formulas 1 and 2). The equivalent strains in case of the investigated samples 2 and 3 was calculated to be $760 \%$, increasing with the rotation number to $830 \%$ in case of the sample 4 . As is shown by the transmission electron microscopy (Fig. 3a,b; 4a,b and 5a,b) the increase of the deformation led to the refinement of the Algraphene composites microstructure. The BF images in Figure 3 show decrease of the dimensions of Al matrix grains after increase of the rotation number in sample 4 . The same conclusion may be draw out from the selected area electron diffractions presented in Figure 4. The continuous rings in SADP in Figure $4 \mathrm{~b}$ proves transition from the small grained but deformation textured microstructure in composite 3 to the much more refined and random oriented grains in sample 4. However, calculation of the $d_{h k l}$ shows that the SADPs from the composites do not contain spots related to the graphene content.
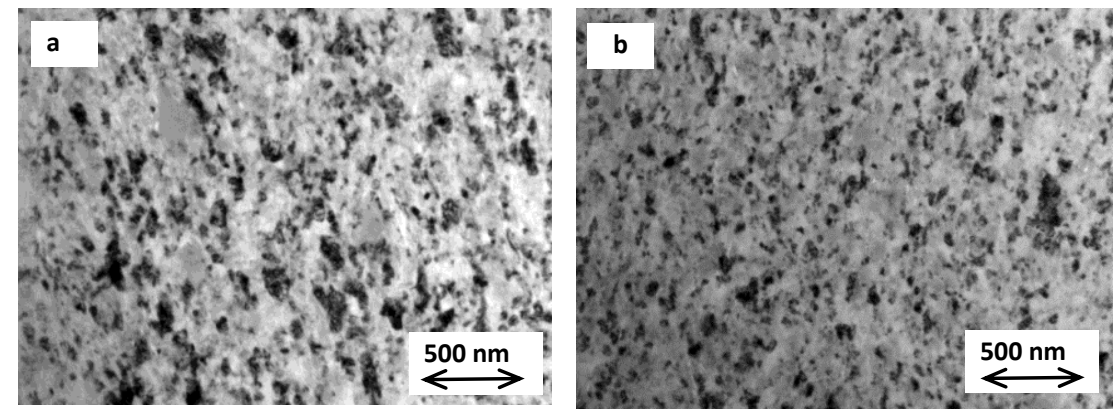

Figure 3. TEM microstructure of the Al-graphene composites, BF technique;

(a)-sample 3 ( $\mathrm{N}=5 \mathrm{rot})$, (b)-sample 4 ( $\mathrm{N}=10 \mathrm{rot})$
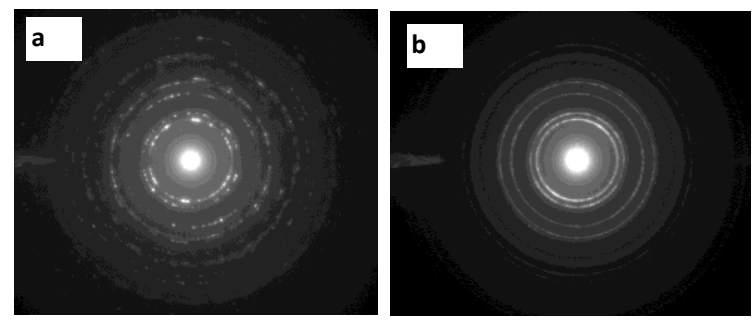

Figure 4. SADPs from the Al-graphene composites, (a) - sample $3(\mathrm{~N}=5$ rot), (b) - sample 4 ( $N=10$ rot) showing more refined microstructure in sample 4 . All the $\mathrm{d}_{\mathrm{hkl}}$ fits to the $\mathrm{Al}$ matrix

The bright, fine contrast visible in Figure 5 may result from the presence of the multilayer nanoparticles of the graphene or graphite but EDS linear analysis show homogenous distribution of the registered content of carbon. 

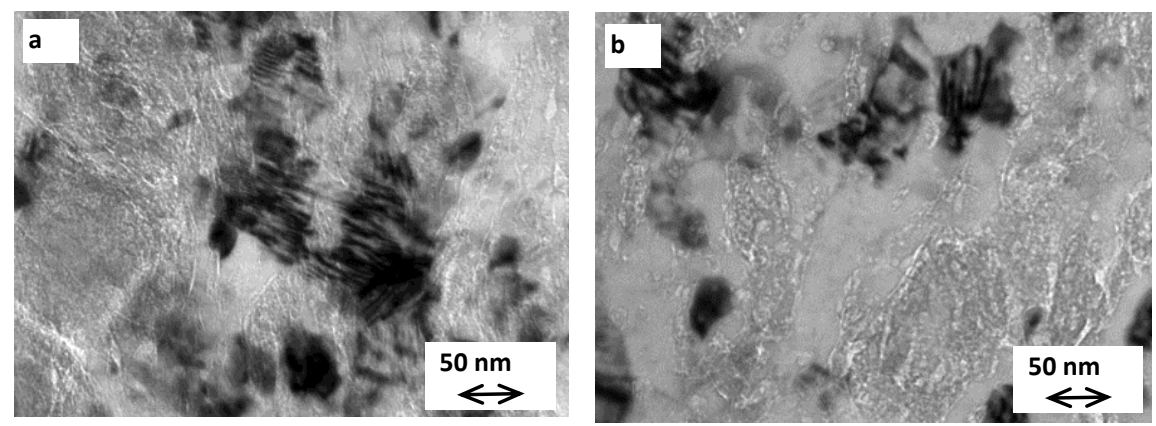

Figure 5. TEM microstructure of the Al-graphene composites with large magnification, BF technique; (a) - sample $3(\mathrm{~N}=5 \mathrm{rot})$, (b) - sample 4 ( $\mathrm{N}=10 \mathrm{rot})$

Nano-twins in the $\mathrm{Al}$ grains and graphene layers (bright contrast) are visible
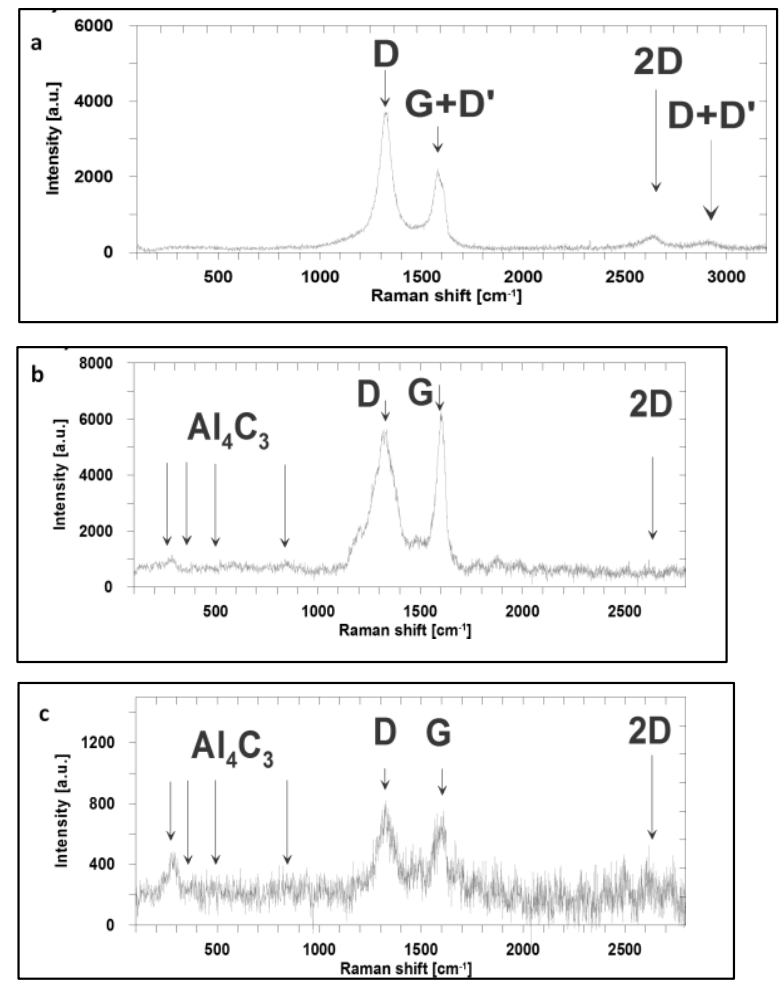

Figure 6. Raman spectra from the samples of: (a) graphene used as an addition, (b, c) composite No. 3. $6 \mathrm{~b}-\mathrm{Al}$ grain surfaces and $6 \mathrm{c}$ dark areas between grains

The results achieved by the Raman spectroscopy on the samples 3 and 4 proved that the composites No. 3 and 4 really contain carbon additions in the form of nano-particles or sheets. The spectra of the used graphene shown in Figure 6a should be interpreted as resulting from the multilayer graphene with defected structure [21]. As may be seen the G peak 

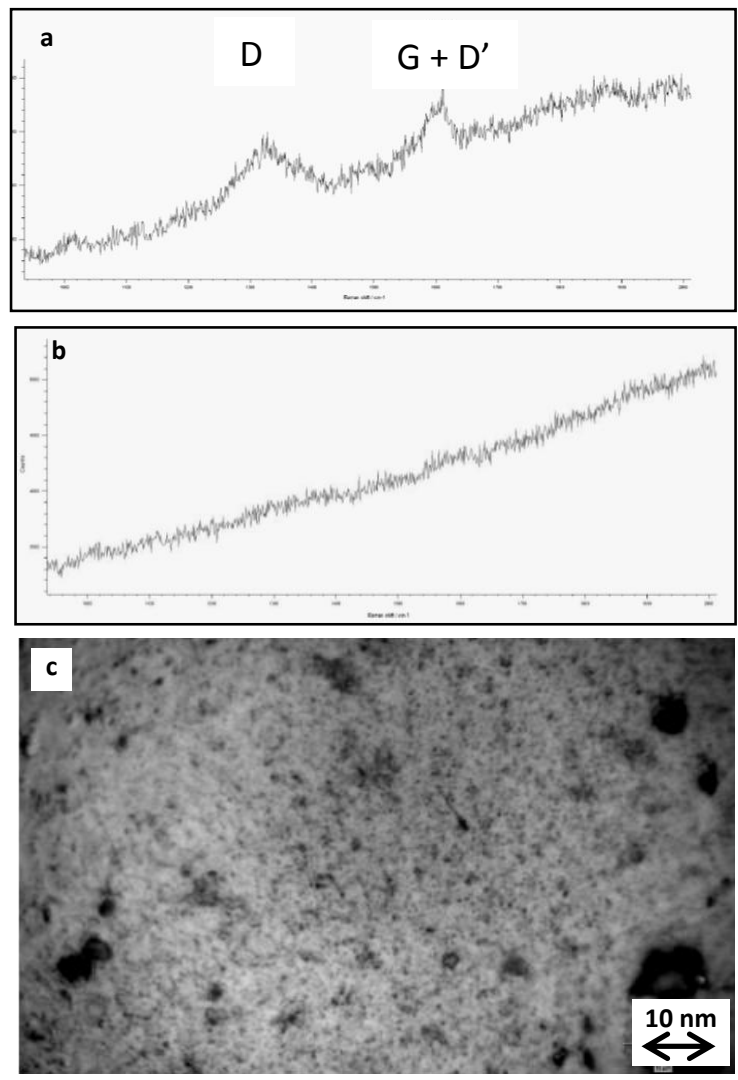

Figure 7. Raman spectra from the sample No. $4 \mathrm{Al}$ - graphene, $\mathrm{N}=10$ rot, a) points in bright $\mathrm{Al}$ grains, b) points in dark places, c) image of the investigated area

$\left(1589 \mathrm{~cm}^{-1}\right)$ is relatively intensive, but not single as in the monolayer graphene [22], while band $2 \mathrm{D}\left(2650 \mathrm{~cm}^{-1}\right)$ which is very intensive and single in non-defected graphene [22], is very small. The same time peaks named D, D' and D+D', which are observed in the damaged graphene are intensive [22]. The typical spectra from the sample No. 3 are shown in Figures $6 b$ - from the bright grain surfaces and $6 c$ - from the dark points between them. In the first case both peak $\mathrm{D}$ and $\mathrm{G}$ are more intensive, with increasing relative intensity of $\mathrm{G}$, what could suggest larger participation of the non-defected monolayer graphene [21,22] but the 2D peak is very small. In the second case (Fig. 6c) general intensity is very small suggesting very small participation of the defected graphene. In both cases some peaks which may be interpreted as coming from $\mathrm{Al}_{4} \mathrm{C}_{3}$ aluminum carbides are visible.

Slightly different results were achieved for the composite sample No. 4, produced with the $\mathrm{N}=10$ rotations (Fig. $7 \mathrm{a}, \mathrm{b})$. In this case proportion of the $\mathrm{D}$ and $\mathrm{G}$ peaks $\mathrm{I}_{\mathrm{D}} / \mathrm{I}_{\mathrm{G}}$ increased from 1.9 to 2.6, what means some increase in the defects density in the multi-layer graphene $[21,23]$ as a result of the increased shear strain. Similarly to the previous sample only bright areas of the matrix grains gave Raman spectra related to the graphene (Fig. 7c). 
Photoelectron spectroscopy was applied to determine atomic bond types existing after the HPT consolidation process, what was also important from the point of view of the bonding between carbon atoms from the graphene and $\mathrm{Al}$ atoms from the matrix. The experiments were performed on the consolidated $\mathrm{Al}$ sample No. 2 and $\mathrm{Al}$-graphene composite, sample No. 3. Except atomic bonds of the types: $\mathrm{C}-\mathrm{O}+\mathrm{C}=\mathrm{O}, \mathrm{CO}_{3}$ and $\mathrm{Al}^{3+}-\mathrm{O}$ which were caused by surface oxidation and bonds of the type $\mathrm{COOH}$ which resulted from the graphene preparation processes, the relative participation of the bonds between carbon atoms $\mathrm{C}-\mathrm{C}$, aluminum atoms $\mathrm{Al}-\mathrm{Al}$ and aluminum - carbon atoms $\mathrm{Al}-\mathrm{C}$ were analyzed from the area of the $\mathrm{C} 1 \mathrm{~s}$ and $\mathrm{Al} 2 \mathrm{p}$ electron lines. The results are summarized in Table 2. The interpretation of the position in energy scale of the components of XPS lines was performed on the base of $[24,25]$. Given in Table 2 their relative participation were calculated neglecting bonds assumed to be surface oxidation and organic solvents remnants.

Table 2. XPS results for the Al-graphene composite and consolidated Al samples prepared in the same way: $\mathrm{C}$ 1s and Al 2p lines positions, relative areas and hypothetical interpretation

\begin{tabular}{|c|c|c|c|}
\hline Sample No. & Bond type & $\begin{array}{c}\text { Position } \\
{[\mathrm{eV}]}\end{array}$ & $\begin{array}{c}\text { Relative area } \\
{[\%]}\end{array}$ \\
\hline \multicolumn{4}{|c|}{$\mathrm{C} 1 \mathrm{~s}$} \\
\hline \multirow{2}{*}{$\begin{array}{l}\text { Al sample } \\
\text { No. } 2\end{array}$} & $\mathrm{C}-\mathrm{Al}$ & 282.8 & 9.3 \\
\hline & $\mathrm{C}-\mathrm{C}$ & 285.3 & 90.7 \\
\hline \multirow{2}{*}{$\begin{array}{l}\text { Al-graphene } \\
\text { No. } 3\end{array}$} & $\mathrm{C}-\mathrm{Al}$ & 233.2 & 27.3 \\
\hline & $\mathrm{C}-\mathrm{C}$ & 285.3 & 72.7 \\
\hline \multicolumn{4}{|c|}{$\mathrm{A} 12 \mathrm{p}$} \\
\hline \multirow[t]{3}{*}{$\begin{array}{l}\text { Al sample } \\
\text { No. } 2\end{array}$} & $\mathrm{Al}-\mathrm{Al}$ & $\begin{array}{l}76.3 \\
74.0\end{array}$ & $\begin{array}{c}34.2 \\
0\end{array}$ \\
\hline & $\mathrm{Al}^{3+}-\mathrm{O}$ & $\begin{array}{l}76.8 \\
77.2\end{array}$ & $\begin{array}{c}64.5 \\
0\end{array}$ \\
\hline & $\mathrm{Al}^{3+}-$ & 79.5 & 1.3 \\
\hline \multirow[t]{3}{*}{$\begin{array}{c}\text { Al-graphene } \\
\text { No. } 3\end{array}$} & $\mathrm{Al}-\mathrm{Al}$ & $\begin{array}{l}73.5 \\
73.9\end{array}$ & $\begin{array}{c}28.7 \\
0\end{array}$ \\
\hline & $\mathrm{Al}^{3+}-\mathrm{O}$ & $\begin{array}{l}76.9 \\
77.3\end{array}$ & $\begin{array}{c}69.0 \\
0\end{array}$ \\
\hline & $\mathrm{Al}^{3+}-$ & 78.8 & 2.3 \\
\hline
\end{tabular}

As is shown in the table in case of Al-graphene composite amount of the metal carbon bonds is 3-times larger in comparison with the Al consolidated sample while participation of the carbon-carbon bonds decreases by about 1.2. Similarly, participation of the metal-metal bonds decreased in case of the composite by about 1.2.

\section{SUMMARY AND CONCLUSIONS}

As results, intensive deformation by high pressure torsion may be successfully used for the production of the Al-graphene composites of homogenous microstructure directly from mixtures of powders or with the additional step of mechanical synthesis. Ball milling 
increases effectiveness of the sample consolidation by HPT increasing ability for shear strain and composite hardness, however may promote both oxidation and Al-carbides formation. The HPT process influences in some part the structure of the multilayer graphene increasing defects density and decreasing particles dimensions. There are also strong indications that shear strains may increase amount of the monolayer graphene, in fact increasing quality of the introduced addition. The increase of the rotation number in HPT refines the composite microstructure and influences graphene structure.

Both results of the TEM observations and Raman spectroscopy suggests that graphene locates at the grain surfaces. It should be pointed to, that while TEM observations were performed at the foil prepared from the cross-section of the sample, the results of the Raman spectroscopy concerns the surface layer of the composite. Results of the photoelectron spectroscopy may lead to the conclusions that the graphene atoms do not remain separated from the surrounding atoms of the metal-matrix but partially form bonds of the Al-C type, decreasing participation of the carbon -carbon bonding. The subject of the reaction of the graphene to the intensive deformation and the surrounding metallic matrix needs much more further investigations.

\section{ACKLOWNEDGEMENTS}

The work was financed by the Project GRAF-TECH/NCBR/10/29/2013 and partially realized in frame of the bilateral cooperation project between IMMS PAS in Krakow and IMSP RAS in Ufa, for 2014-2016 years.

\section{LITERATURE}

[1] NOVOSELOV K.S., GEIM A.K., MOROZOV S.V., JIANG D., ZHANG Y., DUBONOS S.V. at. al., Science 306(5696) (2004) 666.

[2] GEIM A.K., Science 324 (5934) (2009) 1530.

[3] GEIM A.K., NOVOSELOV K.S., Nat Mater 6(3) (2007) 183.

[4] NOVOSELOV K.S., JIANG Z., ZHANG Y., MOROZOV S.V., STORMER H.L., ZEITLER U., et al., Science 315(5817) (2007) 1379.

[5] ROCHA C.G. at.al., Tailoring the Physical Properties of Graphene. In: Graphene, Synthesis and Applications, W. Choi, J. Lee, (eds.), CRC Press, Boca Raton, London, New York 2012, p.1.

[6] LEE C.G., WEI X.D., KYSAR J.W., HONE J., Science 321(5887) 385 (2008).

[7] LAHIRI D., AGARWAL A., Graphene Reinforced Ceramic and Metal Composites. In: Graphene, Synthesis and Applications W. Choi, J. Lee (eds.), CRC Press, Boca Raton, London, New York 2012, p.188.

[8] ROCHA C.G. at.al. Tailoring the Physical Properties of Graphene. In: Graphene, Synthesis and Applications W. Choi, J. Lee (eds)., CRC Press, Boca Raton, London, New York 2012, p.10.

[9] OTSUJI T., SUEMITSU T., SATOU A., SUEMITSU M., SANO E., RYZHII M., RYZHII V. Electronic and Photonic Applications for Ultrahigh-Frequency Graphene-Based Devices. In: Graphene, Synthesis and Applications W. Choi, J. Lee, (eds.) CRC Press, Boca Raton, London, New York 2012, p.85.

[10] PEI S., CHENG H-M., Carbon (2011) doi:10.1016/j.carbon.2011.11.010.

[11] HAWELEK L., et. al, Diamond Relat.Mater. 35 (2013) 40-46.

[12] VALIEV R.Z., ZHILYAEV A.P., LANGDON T.B., Principles and Technical Parameters of High-Pressure Torsion. In: Bulk Nanostructured Materials R.Z. Valiev (ed.) TMS Wiley, Hoboken, New Jersey 2014 pp. 2533.

[13] VALIEV R.Z., ZHILYAEV A.P., LANGDON T.B., HPT Processing of Metals, Alloys and Composites. In: Bulk Nanostructured Materials R.Z. Valiev (ed.) TMS Wiley, Hoboken, New Jersey 2014 pp.88-145.

[14] BARROS A. M., TENÓRIO J. A. S., Intermetallics 13 (2005) 137-140

[15] BARÓ M. D., MLAGELADA J., SURIÑACH S., CLAVAGUERA N. AND CLAVAGUERA-MORA N. T. Calorimetric Study of Reordening of Disordered $\mathrm{Ll}_{2}, \mathrm{Ni}_{3} \mathrm{Al}$ Based Alloys. In: Ordering and disordering in alloys A .R. YAVARI (ed.), Elsevier Applied Science, 1992, pp. 55-66.

[16] KORZNIKOV A.V., DIMITROV O., KORZNIKIOVA G. F., DALLAS J. P., IDRISOVA S. R., VALIEV R. 
Z., FAUDOT F., Acta mater 47 (1999) 3301.

[17] KORZNIKOV A.V., PAKIEŁA Z. AND KURZYDŁOWSKI K.J., Sripta Met.45 (2001) 309-315.

[18] SORT J., ILE D.C., ZHILYAEV A.P., CONCUSTELL A., CZEPPE T., STOICA M., SURIÑACH S., ECKERT J., BARÓ M.D., Sripta Mat. 501221 (2004).

[19] CZEPPE T., KORZNIKOVA G., MORGIEL J., KORZNIKOV A., CHIH N.Q., OCHIN P., SYPIEN A., J. All. Comp. 483 (2009) 74-77.

[20] VAlIEV R.Z., ZHILYAEV A.P., LANGDON T.B., Principles and Technical Parameters of High-Pressure Torsion. In: Bulk Nanostructured Materials R.Z. Valiev (ed.) TMS Wiley, Hoboken, New Jersey 2014 p. 30.

[21] JORIO A., Prototypes for Nanoscience and Nano metrology. In: Raman Spectroscopy in Graphene Based Systems ISRN Nanotechnology, (2012) doi: 10.5402/2012/234216.

[22] FERRARI A.C., MEYER J.C., SCARDACI V. at.al., PRL 97 (2006) 187401.

[23] CHILDRES I., JAUREGUI L.A., PARK W., CAO H., CHEN Y.P., Raman Spectroscopy of Graphene and Related Materials, Chapter 19. In: New Developments in Photon and Materials Research,. J.I. Jang (eds), Nova Science Pub Inc, 2013.

[24] Electron Spectroscopy Database; www.lasurface.com

[25] NIST X-ray Photoelectron Spectroscopy Database; http://srdata.nist.gov/xps/ 